\title{
ESTIMATION OF SERUM COPPER AND ZINC LEVELS IN PATIENTS WITH ORAL CANCER
}

\author{
Savitha Sangappa Shettar ${ }^{1}$
}

${ }^{1}$ Reader, Department of Oral Medicine and Radiology, Al-Badar Dental College and Hospital, Gulbarga.

\begin{tabular}{l} 
ABSTRACT \\
\hline BACKGROUND \\
Oral cancer ranks number one among men and number three among women in India. As micronutrients deficiencies are common \\
in India and have been related to oral and upper aerodigestive tract cancers, it is considered to be necessary as well to study the \\
impact of nutrients. The current study reported is an attempt to suggest a positive role of micronutrients in prevention of cancer.
\end{tabular}

\section{AIMS}

The study was conducted to estimate the serum levels of copper and zinc in patients with oral cancer and to compare these values among patients with oral cancer and normal subjects.

\section{STUDY DESIGN}

The study group consisted of 30 oral cancer patients and 30 normal subjects.

\section{MATERIALS AND METHOD}

Serum levels of copper and zinc were estimated using semi-auto analyser in 30 oral cancer patients and 30 normal subjects.

\section{STATISTICAL ANALYSIS}

Data analysis was carried out using Statistical Package for Social Science (SPSS, V 10.5) package. One-Way Analysis of Variance were used to test the difference between groups and to find out which of the two groups means is significantly different post hoc test of Tukey test was used. In the above test, the " $\mathrm{p}$ " value of less than 0.05 was accepted as indicating statistical significance.

\section{RESULTS}

The mean serum levels of copper and $\mathrm{Cu} / \mathrm{Zn}$ ratio were increased in oral cancer patients compared to normal subjects. The mean serum levels of zinc were decreased in oral cancer patients compared to normal subjects.

\section{CONCLUSION}

Serum levels of these trace elements maybe taken as prognostic markers of the disease progression in oral cancer patients.

\section{KEYWORDS}

Oral Cancer; Trace Elements; Serum Zinc; Serum Copper.

HOW TO CITE THIS ARTICLE: Shettar SS. Estimation of serum copper and zinc levels in patients with oral cancer. J. Evolution Med. Dent. Sci. 2016;5(66):4687-4691, DOI: 10.14260/jemds/2016/1068

\section{INTRODUCTION}

Oral cancer is one of the 10 most cancers in the world and shows a marked geographic difference in occurrence. On the basis of cancer registry data, it is estimated that annually 75,000 to 80,000 new cancer cases develop in India. Oral cancer ranks number one among men and number three among women in India. In the long incubation period between the initiation of carcinogenic habits and development of invasive oral cancer, well-defined oral precancerous lesions such as leucoplakia, submucous fibrosis, and erythroplakia occur.(1)

Tobacco chewing and smoking are strongly related to cancers mainly of upper aerodigestive tract. Several studies on diet and cancer links suggest that micronutrients, particularly

Financial or Other, Competing Interest: None.

Submission 09-07-2016, Peer Review 01-08-2016,

Acceptance 08-08-2016, Published 16-08-2016.

Corresponding Author:

Dr. Savitha Sangappa Shettar,

W/o. Dr. Chandrashekhar Karpoor,

C/o. D.S. Awanti,

H.No.910/156/65, Sedam Road,

Jayanagar, Gulbarga-585105

Karnataka, India.

E-mail: savitha_mds@yahoo.com

DOI: $10.14260 /$ jemds/2016/1068 antioxidants minerals are risk modifiers of cancer.(2) These include selenium, copper, zinc, manganese, and iron.(3) Many elements perform functions indispensable to maintenance of growth and reproduction. Inadequate levels of some elements may impair cellular and physiological functions. Trace elements have been critically examined in aetiology of various diseases, especially cancer.(4)

Several studies have shown that in cancer patients' serum copper levels are of considerable importance in assessing disease activity and prognosis. There are many reasons to assume that the presence of a malignant neoplasm may produce alterations in the micronutrient requirements of the patient. The rapid uncontrolled growth of malignant tissue produces a physiologic stress that may vary depending on the tumour.(5) Poor nutritional status may compromise immune competence and increase damage due to peroxidations. (2)

As micronutrients deficiencies are common in India and have been related to oral and upper aerodigestive tract cancers, it is considered to be necessary as well to study the impact of nutrients. Much more research is needed to characterise better markers of micronutrient status both in terms of metabolic effects and antioxidant effects so that atrisk patients can be identified and supplementation modified accordingly. The current study reported is an attempt to 
suggest a positive role of micronutrients in prevention of cancer.

\section{MATERIALS AND METHODOLOGY}

This study was conducted in the Department of Oral Medicine and Radiology, Government Dental College, Bangalore. 30 patients with oral cancer and 30 age and sex matched healthy controls formed the study group. Patient selection was based on following inclusion and exclusion criteria.

\section{Inclusion Criteria}

- Patients with a definitive diagnosis oral cancer both clinically and histopathologically were included in the study.

\section{Exclusion Criteria}

- Patients who have received treatment for oral cancer previously were excluded from the study.

- Patients with history of diabetes, hypertension, jaundice, liver or kidney disorders, or other systemic diseases and carcinoma elsewhere in the body were excluded from the study.

A detailed case history of the patient was taken and a thorough clinical examination was done and recorded on a standard proforma. Oral cancer patients were grouped clinically according to TNM staging given by American Joint Committee on Cancer(6) and histopathologically as per the Broder's classification. $(7)$

$5 \mathrm{~mL}$ of venous blood was collected using aseptic measures from median cubital vein and sent to laboratories in sterile vials for estimation of serum copper and zinc levels. The blood was allowed to clot at room temperature for 1-2 hrs. and then serum was separated by centrifuging at $3000 \mathrm{rpm}$ for 10 minutes. Serum copper and zinc levels were estimated using colorimetric method. This was followed by a histopathological confirmation of diagnosis by performing an incisional biopsy of the lesion.

\section{SERUM ZINC ESTIMATION \\ Principle}

Nitro-PAPS reacts with zinc in alkaline solution to form a purple coloured complex, the absorbance of which is measured at $575 \mathrm{~nm}$. Interference from copper and iron are virtually eliminated by $\mathrm{pH}$ and chelating additives.

\section{Components}

Reagent A: 5 × $20 \mathrm{~mL}$ (liquid blue cap)

\section{Composition}

Borate buffer: $370 \mathrm{mM}, \mathrm{pH} 8.20$

Dimethylglyoxime: $1.25 \mathrm{mM}$.

Salicylaldoxime: $\quad 12.5 \mathrm{mM}$.

Surfactants and preservatives.

Reagent B: 5 x 5 mL (liquid) red cap

Composizione: Nitro-PAPS $0.40 \mathrm{mM}$.

Standard: Zinc solution $200 \mu \mathrm{g} / \mathrm{dL}-5 \mathrm{~mL}$.

\section{Reagent Preparation}

Mix one vial of reagent $B$ with one vial of reagent $A$.
Specimen: Serum.

\section{Test procedure}

Wavelength: $\quad 575 \mathrm{~nm}$ (allowed $570+$ or $-582 \mathrm{~nm}$ ).

Light path: $1 \mathrm{~cm}$.

Temperature: $\quad 25,30$, or $37 \mathrm{c}$.

Mix, incubate at 25,30 , or $37 \mathrm{c}$ for 5 minutes.

Read absorbances of standard (AS) and samples (Ax) against reagent blank.

\section{Results Calculation}

Serum zinc $\mu \mathrm{g} / \mathrm{dL}=\mathrm{Ax} /$ As $\times 200$ (standard value).

Expected Values: Serum zinc: 70 to $150 \mu \mathrm{g} / \mathrm{dL}$.

\section{SERUM COPPER ESTIMATION:}

Methodology: Colorimetric method.

\section{Principle}

Copper as Cu (II) combines in acidic media with DiBr-PAESA to form a colour complex, the absorbance at which is measured at the interval of 570-590 nm. Sample blank can be avoided as well as serum deproteinisation.

Reagent A 2 × 25 mL (liquid) blue cap Composition: Acetate buffer: $100 \mathrm{mM}, \mathrm{pH} 4.90$, Surfactants and preservatives.

Reagent B 2 × 25 mL (liquid) red cap Composition: 3, 5 DiBr-PAESA: $10 \mathrm{mM}$.

Standard - $5 \mathrm{~mL}$ copper in diluted acid $200 \mu \mathrm{g} / \mathrm{dI}$.

Reagents Preparation: Add a vial of reagent B to a vial of reagent $\mathrm{A}$.

Specimen: Serum.

Manual Assay Procedure

\begin{tabular}{|c|c|c|}
\hline & Reagent Blank & Standard/Sample \\
\hline Standard/sample & - & $100 \mu \mathrm{L}$ \\
\hline Reagent & $1.5 \mathrm{~mL}$ & $1.5 \mathrm{~mL}$ \\
\hline
\end{tabular}

Mix, incubate 10 minutes at 25,30 , or $37^{\circ} \mathrm{C}$. Read absorbances of standard (As) and samples (Ax) at the allowed interval 570 - $590 \mathrm{~nm}$ against reagent blank.

Colour developed is stable at least 20 minutes away from strong light sources.

Calculations

Ax/As x $200=\mu \mathrm{g} / \mathrm{dL}$ copper.

\section{Expected Values}

Men: 80 - $140 \mu \mathrm{g} / \mathrm{dL}$, Women: 80 - $155 \mu \mathrm{g} / \mathrm{dL}$.

\section{Ethics}

A formal ethical clearance to conduct this study was obtained by the Ethical Committee of the college. A formal informed written consent was obtained from all of them.

\section{Statistics}

The following methods of statistical analysis have been used in this study. Data analysis was carried out using Statistical 
Package for Social Science (SPSS, V 10.5) package. One-Way Analysis of Variance were used to test the difference between groups and to find out which of the two groups means is significantly different post hoc test of Tukey test was used. In the above test the "p" value of less than 0.05 was accepted as indicating statistical significance.

\section{RESULTS}

Among 30 oral cancer patients, there were 20 males (66.7\%) and 10 females $(33.3 \%)$ patients. In patients with oral cancer, the mean age was found to be $55.70 \pm 12.65$ years (mean \pm SD) with $30 \%$ in the age group of $50-59$ years, $23.3 \%$ in the age group of 40-49 years, $20 \%$ in the age group of $60-69$ years, $20 \%$ in the age group of $70-79$ years, $3.3 \%$ of patients in the age group of $20-29$ years and $3.3 \%$ of patients in the age group of 30-39 years.

$21(70 \%)$ patients with oral cancer had involvement of buccal region, soft palate was involved in $1(3.3 \%)$, tongue in $1(3.3 \%)$, lower alveolus in $5(16.7 \%)$, and upper alveolus was involved in 2 (6.7\%).

The clinical staging done for oral cancer as per the TNM staging given by American Joint Committee on cancer showed that $2(6.7 \%)$ belonged to stage I, $3(10 \%)$ belonged to stage II, 12 (40\%) belonged to stage III and $13(43.3 \%)$ belonged to stage IV. The histological grading of oral cancer patients as per Broder's classification showed that 13 (43.3\%) were Grade I, 10 (33.3\%) were of Grade II and III, 7 (23.3\%) were of Grade IV.

The mean serum copper level in control group was $124.83 \pm 20.68 \quad$ (mean \pm SD) $\mu \mathrm{g} / \mathrm{dL}$ and $151.20 \pm 11.20$ (mean $\pm \mathrm{SD}$ ) $\mu \mathrm{g} / \mathrm{dL}$ in patients with oral cancer. There was significant increase in the mean serum copper level. Oral cancer patients compared to mean serum copper level in control group. (Table 1).

The mean serum copper level showed an increasing trend through stage I to stage IV oral cancer patients. (Table 2). There was no significant difference in the mean serum copper level among the histological grades of oral cancer patients.

The present study showed that the mean serum zinc level in control group was $119.97 \pm 8.55 \mu \mathrm{g} / \mathrm{dL}$ (mean \pm SD) and in patients with oral cancer were $104.47 \pm 6.34 \mu \mathrm{g} / \mathrm{dL}$ (mean $\pm \mathrm{SD}$ ) (Table 3). The mean serum zinc level was significantly decreased in patients with oral cancer compared with the mean serum zinc level of control group.

There was no statistically significant difference in the mean serum zinc level among the clinical stages and histological grades in oral cancer patients.

The mean serum $\mathrm{Cu} / \mathrm{Zn}$ ratio in control group was $1.11 \pm 0.31$ (mean $\pm S D$ ) and $1.45 \pm 0.15$ (mean $\pm S D$ ) in patients with oral cancer. The mean serum $\mathrm{Cu} / \mathrm{Zn}$ ratio was significantly increased in oral cancer patients when compared to control group. (Table 4).

The mean serum $\mathrm{Cu} / \mathrm{Zn}$ ratio showed an increasing trend through clinical stage I to stage IV oral cancer patients. (Table $5)$.

There was no significant difference in the mean serum $\mathrm{Cu} / \mathrm{Zn}$ ratio among the histological grades oral cancer patients.

\begin{tabular}{|c|c|c|c|c|c|c|c|}
\hline & $\mathbf{N}$ & Mean & Std. Deviation & Minimum & Maximum & \multirow{3}{*}{ F 6.14} & \multirow{3}{*}{$\begin{array}{l}\text { P Value } \\
<0.001\end{array}$} \\
\hline Control & 30 & 124.83 & 20.68 & 70 & 154 & & \\
\hline Oral Cancer & 30 & 151.20 & 11.20 & 128 & 168 & & \\
\hline
\end{tabular}

\begin{tabular}{|c|c|c|c|c|c|c|c|}
\hline & $\mathbf{N}$ & Mean & Std. Deviation & Minimum & Maximum & \multirow{3}{*}{$\mathbf{F}$} & \multirow{3}{*}{$P$ value } \\
\hline Stage I & 2 & 128.00 & .00 & 128 & 128 & & \\
\hline Stage II & 3 & 135.33 & 5.51 & 129 & 139 & & \\
\hline Stage III & 12 & 148.75 & 3.74 & 143 & 154 & \multirow{2}{*}{47.44} & \multirow{2}{*}{$<0.01$} \\
\hline Stage IV & 13 & 160.69 & 5.37 & 152 & 168 & & \\
\hline
\end{tabular}

\begin{tabular}{|c|c|c|c|c|c|c|c|}
\hline & $\mathbf{N}$ & Mean & Std. Deviation & Minimum & Maximum & \multirow{3}{*}{ F 7.98} & \multirow{3}{*}{$\begin{array}{l}\text { P Value } \\
<0.001\end{array}$} \\
\hline Control & 30 & 119.97 & 8.55 & 105 & 135 & & \\
\hline Oral cancer & 30 & 104.47 & 6.34 & 97 & 123 & & \\
\hline
\end{tabular}

\begin{tabular}{|c|c|c|c|c|c|c|c|}
\hline & $\mathbf{N}$ & Mean & Std. Deviation & Minimum & Maximum & F & P \\
Value \\
Control & 30 & 1.1114 & .31566 & .48 & 1.71 & 5.43 & $<0.01$ \\
\hline Oral cancer & 30 & 1.4538 & .15264 & 1.13 & 1.70 & $\mathbf{5}$ \\
\hline \multicolumn{7}{|c|}{ Table 4: Mean Serum Copper/Zinc Ratio Among Study Groups } \\
\hline
\end{tabular}

\begin{tabular}{|c|c|c|c|c|c|c|c|}
\hline & $\mathbf{N}$ & Mean & Std. Deviation & Minimum & Maximum & \multirow{3}{*}{$\mathbf{F}$} & \multirow{3}{*}{$\begin{array}{c}P \\
\text { value }\end{array}$} \\
\hline Stage I & 2 & 1.2367 & .0084 & 1.23 & 1.24 & & \\
\hline Stage II & 3 & 1.2711 & .1364 & 1.13 & 1.40 & & \\
\hline Stage III & 12 & 1.4284 & .0996 & 1.21 & 1.56 & \multirow{2}{*}{8.242} & \multirow{2}{*}{.001} \\
\hline Stage IV & 13 & 1.5527 & .1291 & 1.32 & 1.70 & & \\
\hline
\end{tabular}

\section{DISCUSSION}

In the present study, the mean serum copper levels were increased significantly in patients with oral cancer when compared with that of normal subjects. Studies by J.N. Jha et al in 1985(8) and G.B. Toke in 1990(9) showed elevated levels of serum copper in patients with oral cancer compared to normal 
subjects. It was stated by the authors that the rise in serum copper is possibly due to increase in serum cuproenzyme, ceruloplasmin consequent to decreased catabolism of this enzyme in cancer patients. ${ }^{(8)}$ Fisher et al have suggested that a decrease in catabolism of ceruloplasmin as a possible cause of hypercupraemia seen in malignancy. Resialylation of ceruloplasmin could lead to decreased catabolism by liver and therefore hypercupraemia as binding to ceruloplasmin accounts for $96 \%$ of serum copper.(10) The involvement of copper ions in biological damage caused by superoxide, a radical found in all living tissues has been documented. According to this model, superoxide radical or other reducing agents such as ascorbate reduce the copper complexes to the cuprous state. In turn, these complexes react with hydrogen peroxidase to form hydroxyl radicals that damage proteins, RNA, and most important DNA. Repetitive formation of $\mathrm{OH}$ radicals at a specific location where the copper ions are found is probably the mechanism of this process. These radicals may cause double strand breaks in the cellular DNA that are not repairable by cellular mechanisms thus initiating a malignant process. ${ }^{(11)}$

The present study showed that mean serum zinc levels were decreased in patients with oral cancer compared to that of normal subjects. This finding was similar to that of the study by Iype Varghese et al in 1987.(12) It was stated that a decreased level of serum zinc associated with the carcinogenesis maybe due to increased utilisation of zinc by tumour tissues.

A decreased level of serum zinc in patients with oral cancer when compared with normal subjects was also observed by J. N. Jha et al in 1985(8) and G. B. Toke et al in 1990(9) in their studies. They stated that zinc, which is essential for DNA polymerase activity is particularly important in cell proliferation encountered in growing cell tumour. Perhaps the increased metabolic requirement of zinc by cancer cells results in an increased uptake from serum. Infection and tissue damage, which are often associated with oral carcinoma lead to liberation of leucocytes endogenous mediator from neutrophils, which in turn results in a decrease in serum zinc and concomitant uptake of zinc by the liver.(8)

It is also considered that hypozincaemia in malignant diseases is related to the decreased albumin fraction, which combines with about $60 \%$ of plasma zinc and serves as a transporter of the metal.(13)

Various immunologic abnormalities have been associated with zinc deficiencies in human beings. A mild deficiency of zinc is associated with decreased thymulin activity, reduced ratio of $\mathrm{CD} 4+/ \mathrm{CD} 8+\mathrm{t}$-cells, and decreased production of interleukin-2. The fact that Il-2 plays a central role in maintenance of thymocytic and peripheral $\mathrm{T}$ helper cell population. The generation of antiviral and antitumour specific cytotoxic T-cells, up regulation of natural killer cell lytic activity implies that mild zinc deficiency could also lead to enhanced susceptibility to infection and malignancies by impairing production of this cytokine.(14)

The present study showed an elevation in mean serum $\mathrm{Cu} / \mathrm{Zn}$ ratio in patients with oral cancer compared to normal subjects. Our results were similar to results of study by J.N. Jha et al in $1985^{(8)}$ and G.B. Toke et al in 1990(9) who in their studies showed that there is an increase in level of serum $\mathrm{Cu} / \mathrm{Zn}$ ratio in patients with oral cancer when compared to that of normal subjects. The value of serum $\mathrm{Cu} / \mathrm{Zn}$ ratio increased significantly with the advancing stages of disease, which was also seen in our study groups. It was stated that serum copper is generally increased and serum zinc is generally decreased in cancer patients and also because serum zinc homeostasis is not well regulated as copper homeostasis, the ratio of serum $\mathrm{Cu} / \mathrm{Zn}$ can be considered as a more reliable index of these two elements in patients with cancer of the digestive tract.

M. Abdulla et al in 1979 in their study observed there was a significant decrease in plasma zinc and increase in $\mathrm{Cu} / \mathrm{Zn}$ ratio in plasma of patients with squamous cell carcinoma than in healthy controls. The plasma zinc level was estimated in the same patients after treatment. In patients responding to therapy, zinc and the copper/zinc ratio in the plasma and whole blood became normal. These results suggested a potential screening and predicting value of zinc and the copper/zinc ratio in plasma and whole blood in squamous cell carcinoma of the head and neck.(15)

In a study by S. Khanna et al in 2006 showed a gradual increase in serum copper levels from precancer to cancer group as compared to normal and suggested a positive role of copper ions in tissue damage.(16)

Study by Apeksha R.et al in 2010 showed increase in serum copper levels, decrease in serum zinc levels, and elevated levels of $\mathrm{Cu} / \mathrm{Zn}$ ratio in patients with oral cancer similar to findings of our study. It was stated that elevated copper is comparable with that of other malignancies like lymphoma, lung cancer, and breast cancer. Association of elevated copper levels in oral cancer can be correlated to its role in tumour angiogenesis, which is responsible for tumour development and progression. Decreased levels of zinc could be because the malignant cells probably require more zinc, which is taken up from serum and hence there is a decreased serum level of zinc in patients with oral cancer. As there is negative interaction between copper and zinc, hence increases in copper levels will cause decrease in zinc level.(17)

Study by S. Khanna et al in 2013 demonstrates that there is an alteration in trace element profile in serum the OSMF and OSCC patients when compared to the control group. An attempt was made to assess these parameters as predictors for disease occurrence and progression. An analysis of the data indicates a direct relationship of serum $\mathrm{Cu}$ with the incidence of disease. The association of disease occurrence with $\mathrm{Zn}$ was not clear and less conclusive. It was concluded that $\mathrm{Cu}$ and $\mathrm{Zn}$ play an important role in oral carcinogenesis, but further research was warranted on larger population.(18)

Study done by Amith Kumar et al in 2014 showed the finding of low levels of zinc and copper associated with oral cancer patients. They also stated that copper/zinc ratio may serve as good indicator for the early detection of oral cancer and zinc deficiencies impair host protective mechanism designed to protect against DNA damage enhances susceptibility to DNA damaging agents and ultimately increase the risk of cancer.(19)

\section{CONCLUSION}

Our study showed change in serum levels of zinc, copper, and copper/zinc ratio in patients with oral cancer compared to that of normal subjects. On the basis of this study, it can be suggested that serum levels of these biochemicals may be used as prognostic markers in oral cancer patients and this biochemical assessment can be of value for proactive 
intervention of high-risk groups. But to validate the above results, further studies on large sample size are required.

\section{REFERENCES}

1. Sankaranarayanan R. Oral cancer in India: an epidemiologic and clinical review. Oral Surg Oral Med Oral Pathol 1990;69(3):325-30.

2. Krishnaswamy K, Prasad MP, Krishna TP, et al. A case study of nutrient intervention of oral precancerous lesions in India. Eur J Cancer B Oral Oncol 1995;31B(1):41-8.

3. Enwonwu CO, Meeks VI. Bio nutrition and oral cancer in humans. Crit Rev Oral Biol Med 1995;6(1):5-17.

4. Vyas RK, Gupta AP, Gupta A, et al. Serum copper, zinc, magnesium, and calcium levels in various human diseases. Indian J Med Res 1982;76:301-4.

5. Hoffman FA. Micronutrient requirements of cancer patients. Cancer 1985;55(1 Suppl):295-300.

6. Martin SG, Michael G. Burket's oral medicine diagnosis and treatment. 10 ${ }^{\text {th }}$ edn. Harcourt (India) Private Limited 2003.

7. Harsh M. Textbook of Pathology. $3^{\text {rd }}$ edn. Jaypee Medical Publishers (P) Ltd 1998.

8. Jha IN, Singh HB, Prasad N. Serum copper/zinc ratio in oral carcinoma. Indian J Med Res 1985;81:602-6.

9. Toke GB, Dhamne BK. A study of serum copper, serum zinc, and $\mathrm{Cu} / \mathrm{Zn}$ ratio as diagnostic and prognostic index in cases of head, neck, and face tumours. Indian J Pathol Microbiol 1990;33(2):171-4.

10. Shah I, Lewkow LM, Khilanani U. Correlation of hypercupraemia with other acute phase reactants in malignant lymphoma. Cancer 1983;51(5):851-4.

11. Margalioth EJ, Schenker JG, Chevion M. Copper and zinc levels in normal and malignant tissues. Cancer 1983;52(5):868-72.
12. Varghese I, Sugathan CK, Balasubramoniyan G, et al. Serum copper and zinc levels in premalignant and malignant lesions of the oral cavity. Oncology 1987;44(4):224-7.

13. Inutsuka S, Araki S. Plasma copper and zinc levels in patients with malignant tumours of digestive organs. Clinical evaluation of the $\mathrm{C} 1 / \mathrm{Zn}$ ratio. Cancer 1978;42(2):626-31.

14. Anand SP, Joseph K, Frances WJB, et al. Trace elements in head and neck cancer patients: zinc status and immunologic functions. Otolaryngol Head Neck Surg 1997;116(6):624-9.

15. Abdulla M, Biorklund A, Mathur A, et al. Zinc and copper levels in whole blood and plasma from patients with squamous cell carcinomas of head and neck. Journal of Surgical Oncology 1979;12(2):107-13.

16. Khanna SS, Karjodkar FR. Circulating immune complexes and trace elements (copper iron and selenium) as a marker in oral precancer and cancer: a randomised controlled clinical study. Head and Face Medicine 2006;2:33.

17. Balpande AR, Sathawane RS. Estimation and comparative evaluation of serum iron, copper, zinc, and copper/zinc ratio in oral leucoplakia, submucous fibrosis, and squamous cell carcinoma. Journal of Indian Association of Medicine and Radiology 2010;22(2):73-6.

18. Khanna S, Udas AC, Kumar GK, et al. Trace elements (copper, zinc, selenium, and molybdenum) as markers in oral submucous fibrosis and oral squamous cell carcinoma. Journal of Trace Elements in Medicine and Biology 2013;27(4):307-11.

19. Kumar A, Kumari S, Poojary D, et al. Estimation of serum micronutrient levels and the possible risk of oral cancer and premalignancy. International Journal of Innovative Research in Science, Engineering, and Technology 2014;3(1):8360-3. 